\section{(2) OPEN ACCESS}

\title{
Performance evaluation of automated urine microscopy as a rapid, non-invasive approach for the diagnosis of non-gonococcal urethritis
}

\author{
Marcus J Pond, ${ }^{1}$ Achyuta V Nori, ${ }^{1}, 2$ Sheel Patel, ${ }^{2}$ Ken Laing, ${ }^{1}$ Margarita Ajayi, ${ }^{1}$ \\ Andrew J Copas, ${ }^{3}$ Philip D Butcher, ${ }^{1}$ Phillip Hay, ${ }^{1,2}$ Syed Tariq Sadiq ${ }^{1,2}$
}

- Additional material is published online only. To view please visit the journal online (http://dx.doi.org/10.1136/ sextrans-2014-051761).

${ }^{1}$ Institute for Infection and Immunity, St George's University of London, London, UK

${ }^{2}$ Department of Genitourinary \& HIV Medicine, St George's Healthcare NHS Trust, London, UK

${ }^{3}$ Research Department of Infection and Population Health, University College London, Mortimer Market Centre, London, UK

\section{Correspondence to} Dr Tariq Sadiq, Institute for Infection and Immunity, St George's University of London, London SW17 ORE, UK; ssadiq@sgul.ac.uk

Conference presentations: Parts of this work were presented at The International Union against Sexually Transmitted Infections 2012, Melbourne, Australia, and the 2014 STD Prevention Conference, Atlanta, USA.

Received 7 July 2014 Revised 22 October 2014 Accepted 22 October 2014 Published Online First 22 January 2015

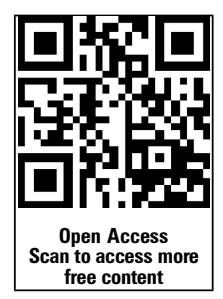

CrossMark

\section{ABSTRACT}

Objectives Gram-stained urethral smear (GSUS), the standard point-of-care test for non-gonococcal urethritis (NGU) is operator dependent and poorly specific.

The performance of rapid automated urine flow cytometry (AUFC) of first void urine (FVU) white cell counts (UWCC) for predicting Mycoplasma genitalium and Chlamydia trachomatis urethral infections was assessed and its application to asymptomatic infection was evaluated. Methods Receiver operating characteristic curve analysis, determining FVU-UWCC threshold for predicting M. genitalium or C. trachomatis infection was performed on 208 'training' samples from symptomatic patients and subsequently validated using 228 additional FVUs obtained from prospective unselected patients.

Results An optimal diagnostic threshold of $>29 \mathrm{UWC} / \mu \mathrm{L}$ gave sensitivities and specificities for either infection of $81.5 \%(95 \% \mathrm{Cl} 65.1 \%$ to $91.6 \%)$ and $85.8 \%(79.5 \%$ to $90.4 \%)$, respectively, compared with $86.8 \%(71.1 \%$ to $95 \%)$ and $64.7 \%$ (56.9\% to $71.7 \%)$, respectively, for GSUS, using the training set samples. FVU-UWCC demonstrated sensitivities and specificities of $69.2 \%(95 \% \mathrm{Cl} 48.1 \%$ to $84.9 \%)$ and $92 \%(87.2 \%$ to $95.2 \%$ ), respectively, when using validation samples. In asymptomatic patients where GSUS was not used, AUFC would have enabled more infections to be detected compared with clinical considerations only $(71.4 \%$ vs $28.6 \% ; p=0.03)$. The correlation between UWCC and bacterial load was stronger for $M$. genitalium compared with C. trachomatis $(\tau=0.426, p \leq 0.001$ vs $\tau=0.295$, $p=0.022$, respectively).

Conclusions AUFC offers improved specificity over microscopy for predicting C. trachomatis or M. genitalium infection. Universal AUFC may enable non-invasive diagnosis of asymptomatic NGU at the PoC. The degree of urethral inflammation exhibits a stronger association with pathogen load for M. genitalium compared with C. trachomatis.

\section{INTRODUCTION}

Non-gonococcal urethritis (NGU) is diagnosed at the point of care $(\mathrm{PoC})$ by demonstrating $\geq 5$ polymorphonuclear cells per high power field (PMN/ HPF) on a Gram-stained urethral smear (GSUS) or $\geq 10$ PMN/HPF from first void urine (FVU) sample sediments. ${ }^{1}$ These thresholds were derived from studies predicting urethral infection prior to implementation of nucleic acid amplification testing (NAAT). ${ }^{23}$ Taking urethral swabs for GSUS is uncomfortable for patients. ${ }^{4}$ Furthermore, microscopy requires skilled personnel and possesses significant inter-user and intra-user variability, ${ }^{6}{ }^{6}$ variable sensitivity and low specificity for predicting infection. ${ }^{7}$ Reduced use of microscopy for asymptomatic patients and the expansion of 'test and treat' community-based sexually transmitted infection screening programmes for Chlamydia trachomatis infection only reduce the potential for empirically treating other infective causes of NGU, such as Mycoplasma genitalium.

With a few accurate specific PoC tests for common microbiological causes of NGU available, a rapid, reproducible, cost-effective and accurate alternative to GSUS is required. Automated urine flow cytometry (AUFC) of mid-stream urine is widely adopted by microbiology laboratories for diagnosing urinary tract infections. ${ }^{8-10}$ This method may also be suitable for diagnosing urethritis if deployable near sexual health clinics, but this has not been evaluated. We compared the test performance of GSUS with AUFC of FVU specimens for predicting male urethral infection with either M. genitalium or C. trachomatis in cases of symptomatic and asymptomatic NGU.

\section{PATIENTS AND METHODS}

\section{Training samples}

Samples were collected as part of a previous study determining the prevalence of aetiological agents of urethritis. ${ }^{11}$ Men with symptoms suggestive of urethritis, prospectively presenting to the genitourinary medicine (GUM) clinic at St George's Healthcare National Health Service Trust between 28 September 2011 and 15 December 2011, undergoing routine GSUS were eligible for inclusion. Patients were designated as having either 'urethritis' or 'no urethritis', as described previously, ${ }^{11}$ but excluded if GSUS, NAAT or culture indicated the presence of Neisseria gonorrhoeae.

\section{Validation samples}

All men attending GUM between 31 July 2013 and 15 September 2013. Following sample collection, only symptomatic patients underwent GSUS testing, a standard-stratified care pathway as GSUS of asymptomatic men reveals a few extra patients with urethritis. ${ }^{12}$ All patients underwent AUFC but were excluded if GSUS or subsequent NAAT or culture results indicated N. gonorrhoeae presence.

\section{Sample collection and processing}

All subjects provided a FVU sample $(10-50 \mathrm{~mL})$, not having voided urine for at least $2 \mathrm{~h}, 2 \mathrm{~mL}$ of 
which was sent for routine C. trachomatis and N. gonorrhoeae NAAT with BD Viper Qx System (Becton Dickinson, Oxford, UK). A further $2 \mathrm{~mL}$ was sent immediately for AUFC. Following measurement of residual volume, ${ }^{13}$ nucleic acids were extracted from FVU as previously described. ${ }^{11}$ AUFC of FVU samples was performed using UF-100i urine flow cytometer (Sysmex, Milton Keynes, UK). Urinary white cell counts (UWCC) were enumerated per $\mu \mathrm{L}$ of urine.

\section{PCR}

Endpoint real-time PCR was performed as described previously ${ }^{2}$ using probe sets enabling detection of C. trachomatis $^{14}$ and M. genitalium. ${ }^{15}$ Droplet digital PCR (ddPCR) was used to determine pathogen genome copies per $\mathrm{mL}$ of original volume of FVU collected. Briefly, reaction mixtures of a final volume of $20 \mu \mathrm{L}$ were generated in triplicate, each comprising $10 \mu \mathrm{L}$ of ddPCR Master Mix (Bio-Rad), relevant forward and reverse primers and probe and $8 \mu \mathrm{L}$ of extracted DNA. Droplets were generated using each $20 \mu \mathrm{L}$ reaction and $60 \mu \mathrm{L}$ of droplet generation oil using a droplet generator cartridge and droplet generator (Bio-Rad). Following dispersion, reactions were transferred into 96-well plates (Eppendorf, Stevenage, UK), heat sealed with foil and amplified using the following conditions: $10 \mathrm{~min}, 95^{\circ} \mathrm{C}$; 40 cycles of $15 \mathrm{~s}$ at $94^{\circ} \mathrm{C}$ and $60 \mathrm{~s}$ at $60^{\circ} \mathrm{C}$ and $10 \mathrm{~min}$ final inactivation, $98^{\circ} \mathrm{C}$. Fluorescence-positive droplets for each sample were enumerated using QuantaSoft software package and QX100 instrument (Bio-Rad).

\section{Statistical analysis}

Previous work ${ }^{7}$ suggested that GSUS has $63 \%$ specificity for diagnosing C. trachomatis. The training set data for this study were drawn from a previously reported prevalence-of-infection study, ${ }^{11}$ with a sample size of approximately 100 samples from each of symptomatic non-urethritis and urethritis patients. This sample set was deemed suitable for the training set as it allowed an increase in specificity of UWCC over GSUS of $15 \%$ to be detected with $>90 \%$ power, $(\alpha=0.05)$, but was too small to detect changes in sensitivity. The goal of our study was to investigate specificity improvements. In order to achieve a diagnostic specificity and $95 \%$ confidence range comparable to those observed in the training sample analysis, 220 prospective samples in total were collected for the validation set. Receiver operating characteristic (ROC) curves of AUFC performance for the prediction of either C. trachomatis or M. genitalium infection were derived from training set data. Non-parametric cumulative distribution functions for the ROC curves were drawn empirically and area under the curve was determined. Optimal thresholds of test positivity were defined using Youden's index of J.

For the training set, AUFC performance for predicting infection was compared with GSUS. For the validation set, in two planned additional analyses we first compared UWCC performance alone against combined use of UWCC with GSUS in order to explore the impact of retaining GSUS for N. gonorrhoeae detection in symptomatic patients; second, we focused on asymptomatic patients where GSUS is not used and where treatment decisions are based on clinical or epidemiological considerations alone and compared those infected with C. trachomatis or M. genitalium who received treatment with those who would have received treatment if UWCC were used to aid diagnosis at the PoC. The validation set was selected to show equivalent specificity and also derives information regarding the performance of the assay in routine use.

In these three analyses, comparisons were made using McNemar's test for paired binary data. $\chi^{2}$ tests were used to detect differences in symptoms and pathogen prevalence between urethritis and non-urethritis groups within the training set. Correlations between discrete variables were assessed using Kendall tau rank correlation coefficient. UWCC and bacterial load distributions were compared using Mann-Whitney U test. Statistical analyses were performed using SPSS V.21.

This study was approved by Wandsworth Research Ethics Committee, London (project number: Q080371).

\section{RESULTS}

\section{Training set}

FVU specimens were collected from 208 symptomatic patients (mean age 31 years), 104 with urethritis and 104 with nonurethritis defined clinically as above. As expected, symptoms of urethral discharge $(69 \%$ vs $50 \% ; \mathrm{p} \leq<0.001)$ and dysuria $(45 \%$ vs $27 \% ; \mathrm{p}=0.009$ ) were higher in the urethritis group compared with non-urethritis group, respectively, but there was no difference in proportions reporting discomfort $(21 \%$ vs $27 \%$, respectively; $\mathrm{p}=0.330$ ).

Overall prevalence of urethral pathogens was $10.5 \%(\mathrm{n}=22)$ for M. genitalium and 7.6\% $(\mathrm{n}=16)$ for C. trachomatis. Both infections were more prevalent in those diagnosed with urethritis: M. genitalium was detected in $16.3 \%(\mathrm{n}=17)$ of urethritis patients and $4.8 \%(\mathrm{n}=5)$ of non-urethritis patients $(\mathrm{p}=0.007)$. C. trachomatis was detected in $14.4 \%(\mathrm{n}=15)$ of urethritis cases and $1 \%(\mathrm{n}=1)$ of non-urethritis cases $(\mathrm{p} \leq 0.001)$. No patients were dually infected with M. genitalium and C. trachomatis.

\section{First void UWCC and GSUS associated with urethral infection within the training set}

Grading of GSUSs demonstrated a difference in distribution between urethritis groups compared with non-urethritis groups $(\mathrm{p} \leq 0.001)$ (see figure 1). As expected, $68 \%(\mathrm{n}=71)$ of patients in the urethritis group demonstrated more than $10 \mathrm{PMN} / \mathrm{HPF}$ (median >20 PMN/HPF). Within the non-urethritis group, 96.1\% $(n=100)$ of patients possessed less than $10 \mathrm{PMN} / \mathrm{HPF}$ (median <5 PMN/HPF). Four patients in the non-urethritis group had a microscopy grade of 5-10 PMN/HPF, but were included in the non-urethritis group on clinical grounds.

UWCC measured by AUFC were increased in the urethritis group (median 13.7 UWCC/ $\mu \mathrm{L}$ ) when compared with the nonurethritis group (median $4 \mathrm{UWCC} / \mu \mathrm{L} ; \mathrm{p} \leq 0.001$ ). A correlation between increasing UWCC and GSUS grade was observed (see figure $1, \tau=0.374, \mathrm{p}<0.001$ ). No correlation between the volume of FVU received and UWCC/ $\mu \mathrm{L}$ was observed $(\tau=-0.059, p=0.201)$.

Patients infected with either C. trachomatis or M. genitalium had increased GSUS grades and median UWCC compared with non-infected patients (10-20 PMN/HPF vs $1-5 \mathrm{PMN} / \mathrm{HPF}$, respectively, $\mathrm{p}<0.001$; and $73 \mathrm{UWCC} / \mu \mathrm{L}$ vs $5 \mathrm{UWCC} / \mu \mathrm{L}$, respectively, $\mathrm{p} \leq 0.001$, see figure $1 \mathrm{~B}$ ).

\section{Assignment of threshold to predict urethral infection from UWCC}

In order to investigate the diagnostic utility of AUFC-UWCC, an ROC curve was plotted (see online supplementary figure S3). Youden's index analysis gave an indicative threshold for predicting either C. trachomatis or M. genitalium infection of $\geq 29 \mathrm{UWCC} / \mu \mathrm{L}$ (Youden's index=0.675). At this threshold, UWCC had a similar sensitivity to GSUS, $81.5 \%$ (95\% CI $65.1 \%$ to $91.6 \%$ ) versus $86.8 \%$ (95\% CI $71.1 \%$ to $95 \%$ ), respectively, and significantly improved specificity $(\mathrm{p}<0.001)$ and positive predictive value $(85.8 \%$ (95\% CI $79.5 \%$ to $90.5 \%)$ vs $64.7 \%$ (95\% CI $56.9 \%$ to $71.7 \%$ ) respectively; see table 1$)$. 

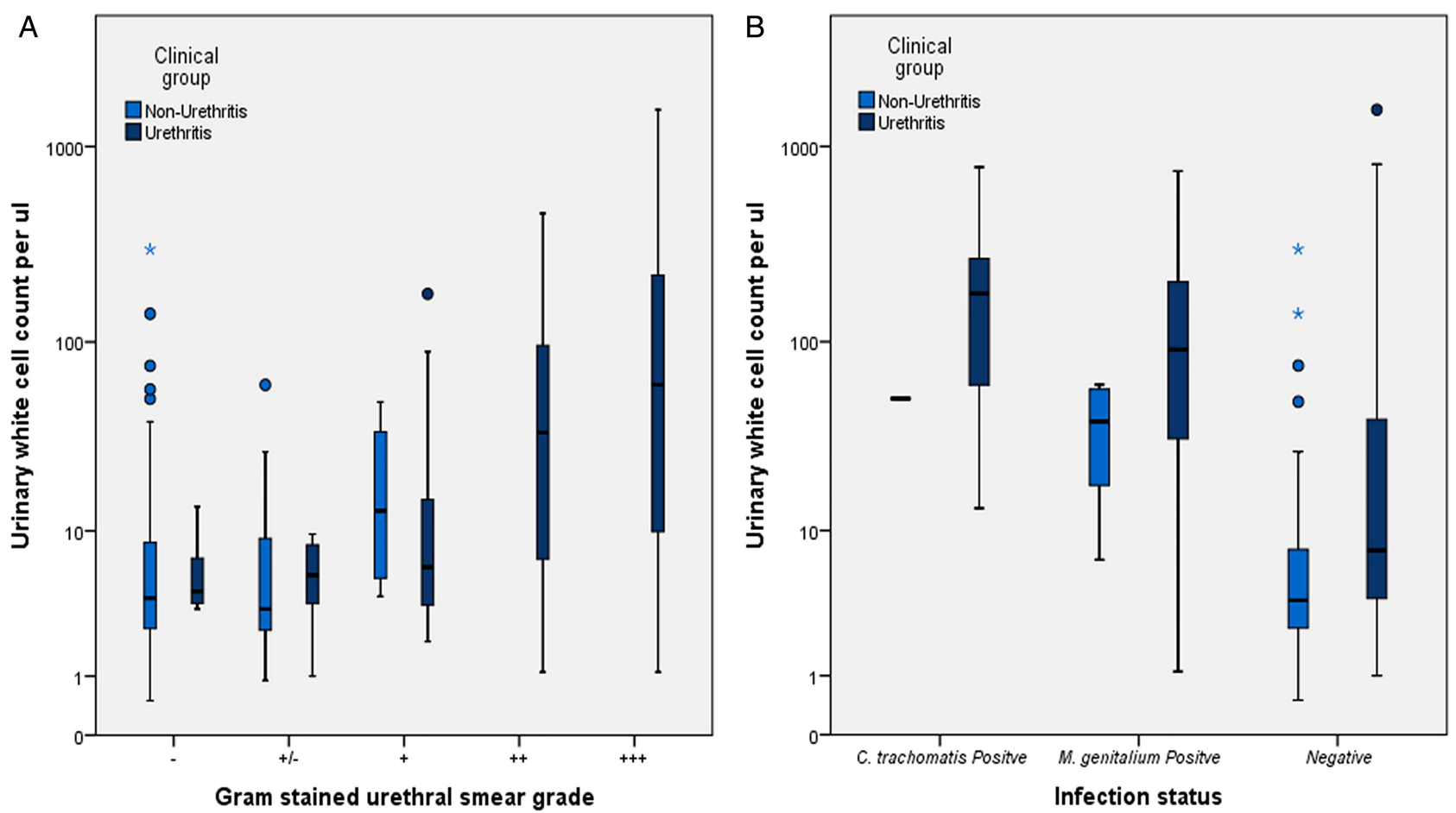

Figure 1 Box plots comparing the distributions of first void urinary white cell counts (UWCC) per $\mu \mathrm{L}$ in patients with and without urethritis stratified by urethral smear grade (A) and C. trachomatis or $M$. genitalium infection status (B). Training set patients only. The median urinary white cell count increases as the urethral smear grade increases $(A, p \leq 0.001)$. UWCC are increased in infected patients with respect to non-infected patients $(B, p \leq 0.001)$, regardless of clinical grouping. Negative Gram-stained urethral smear (GSUS): ' - ' (0 PMN/HPF), ' $-/+$ ' (1-5 PMN/HPF). Positive GSUS: ' + ' (5-10 PMN/HPF), '++' (10-20 PMN/HPF) and '+++' (>20 PMN/HPF). PMN/HPF, polymorphonuclear cells per high power field.

\section{Validation set}

Of 228 patients providing FVU specimens (mean age 32 years), $22 \%(n=52)$ were symptomatic and therefore had GSUS, and 9\% $(\mathrm{n}=20)$ demonstrated $>10 \mathrm{PMN} / \mathrm{HPF}$. Overall C. trachomatis and M. genitalium prevalence was $6 \%(\mathrm{n}=14)$ and $5 \%$ $(\mathrm{n}=12)$, respectively. Among symptomatic patients, M. genitalium and C. trachomatis prevalence was $8 \%(\mathrm{n}=4)$ and $17 \%$ $(n=9)$, respectively, and among asymptomatic patients was $3 \%$ $(n=5)$ and $5 \%(n=8)$, respectively. No correlation was observed between FVU volume and UWCC $(\tau=-0.070, \mathrm{p}=0.120)$.

\section{First void UWCC test performance for prediction of C. trachomatis or M. genitalium infection}

The $\geq 29$ UWCC/ $\mu \mathrm{L}$ threshold derived from the training set was applied to the independent validation set. Sensitivities, specificities and predictive values are shown in table 2. As expected, there was a reduction in sensitivity compared with the training set, although specificity remained high.

Additional analysis demonstrated that combining UWCC with GSUS for symptomatic patients resulted in slightly decreased test specificity $(89.1 \%$ vs $92 \%, p=0.03)$ when compared with UWCC alone (see table 2).

In asymptomatic patients $(n=176)$, combining UWCC testing with epidemiological suspicion of infection and subsequent treatment improved sensitivity $(71.4 \%$ vs $28.6 \%, \mathrm{p}=0.031)$, but reduced specificity $(90.1 \%$ vs $96.3 \%, \mathrm{p}=0.031)$ when compared with combining epidemiological suspicion and treatment alone (see table 2).

\section{Associations between bacterial load and UWCC}

There was no difference in FVU bacterial loads between M. genitalium-infected patients $(n=34)$ and C. trachomatis-infected patients $(n=30)$, derived from both training and validation sets (median 256.9 copies $/ \mathrm{mL}$ cf 194.7 copies $/ \mathrm{mL}$, respectively; $\mathrm{p}=0.389$ ). The median FVU bacterial load, whether combined or for each organism, was higher in those with positive UWCC tests ( $\geq 29$ UWCC/mL), compared with those with negative UWCC tests ( 470 copies $/ \mathrm{mL}$ of 36.8 copies $/ \mathrm{mL}$, respectively, for M. genitalium and C. trachomatis combined, $\mathrm{p}=0.001 ; 538.7$ copies $/ \mathrm{mL} \quad$ cf 91.1 copies $/ \mathrm{mL}$, respectively, for $M$. genitalium only, $\mathrm{p}=0.02$; 306.9 copies $/ \mathrm{mL}$ cf 15.4 copies $/ \mathrm{mL}$, respectively, for C. trachomatis only, $\mathrm{p}=0.005$ ). UWCC were higher in C. trachomatis-infected patients compared with M. genitalium-infected patients (median, 83.7 UWCC $/ \mu \mathrm{L}$ of $49 \mathrm{UWCC} / \mu \mathrm{L}$, respectively, $\mathrm{p}=0.024)$. UWCC were positively correlated with $M$. genitalium bacterial load (see online supplementary figure S2A, $\tau=0.426, \mathrm{p} \leq 0.001$ ) and more weakly correlated with C. trachomatis bacterial load (see online supplementary figure S2B, $\tau=0.295, \mathrm{p}=0.022$ ). Bacterial loads were not statistically different between GSUS-positive and GSUS-negative patients, whether asymptomatic or symptomatic (median 305.5 copies $/ \mathrm{mL}$ cf 139.9 copies $/ \mathrm{mL}$, respectively; $\mathrm{p}=0.58$ ).

\section{DISCUSSION}

We observed that AUFC of total white cell count from first void male urine samples, using a small bench-top AUFC system, suitable for implementation within or near GUM clinic settings, improved performance for predicting either C. trachomatis or M. genitalium urethritis in comparison with GSUS, counting neutrophils per HPF. The automated urine test has the potential to identify patients with asymptomatic urethritis in a non-invasive manner.

A UWCC threshold of $>29 / \mu \mathrm{L}$ applied to symptomatic patients demonstrated improved specificity $(85.8 \%$ vs $64.7 \%)$ and positive predictive value $(56.3 \%$ vs $35.4 \%)$ when compared with GSUS for predicting either infection. Subsequent testing 
Table 1 Comparison of FVU-UWCC with GSUS test performance for the prediction of either Chlamydia trachomatis or Mycoplasma genitalium infection using training set samples

\begin{tabular}{|c|c|c|c|c|c|c|c|c|c|c|}
\hline \multirow[b]{2}{*}{ Test organism } & \multicolumn{2}{|l|}{ Sensitivity } & \multirow[b]{2}{*}{ p Value* } & \multicolumn{2}{|l|}{ Specificity } & \multirow[b]{2}{*}{$p$ Value* } & \multicolumn{2}{|c|}{ Positive predictive value } & \multicolumn{2}{|c|}{ Negative predictive value } \\
\hline & uwCCt & GSUS & & UWCCt & GSUS $\ddagger$ & & uwCCt & GSUS & UwCCt & GSUS \\
\hline C. trachomatis & $\begin{array}{l}93.7 \% \\
(67.7 \% \text { to } 99.6 \%)\end{array}$ & $\begin{array}{l}93.7 \% \\
(67.7 \% \text { to } 99.6 \%)\end{array}$ & 1 & $\mathrm{~N} / \mathrm{A}$ & $\mathrm{N} / \mathrm{A}$ & & $\begin{array}{l}28.3 \% \\
(17.1 \% \text { to } 42.5 \%)\end{array}$ & $\begin{array}{l}16.1 \% \\
\text { (9.6\% to } 25.5 \%)\end{array}$ & $\begin{array}{l}99.3 \% \\
(95.8 \% \text { to } 99.9 \%)\end{array}$ & $\begin{array}{l}99.1 \% \\
(94.5 \% \text { to } 99.9 \%\end{array}$ \\
\hline M. genitalium & $\begin{array}{l}72.7 \% \\
\text { (49.5\% to } 88.3 \%)\end{array}$ & $\begin{array}{l}81.8 \% \\
\text { (58.9\% to } 94 \%)\end{array}$ & 0.72 & N/A & $\mathrm{N} / \mathrm{A}$ & & $\begin{array}{l}29 \% \\
(18 \% \text { to } 43 \%)\end{array}$ & $\begin{array}{l}19.3 \% \\
(12.1 \% \text { to } 29.1 \%)\end{array}$ & $\begin{array}{l}96 \% \\
(91.2 \% \text { to } 98.3 \%)\end{array}$ & $\begin{array}{l}96.5 \% \\
(90.8 \% \text { to } 98.8 \%\end{array}$ \\
\hline $\begin{array}{l}\text { C. trachomatis or } \\
\text { M. genitalium }\end{array}$ & $\begin{array}{l}81.5 \% \\
\text { (65.1\% to } 91.6 \%)\end{array}$ & $\begin{array}{l}86.8 \% \\
\text { (71.1\% to } 95 \%)\end{array}$ & 0.75 & $\begin{array}{l}85.8 \% \\
(79.5 \% \text { to } 90.4 \%)\end{array}$ & $\begin{array}{l}64.7 \% \\
\text { (56.9 to } 71.7 \% \text { ) }\end{array}$ & $<0.001$ & $\begin{array}{l}56.3 \% \\
\text { (42.3\% to } 69.4 \%)\end{array}$ & $\begin{array}{l}35.4 \% \\
\text { (26\% to } 46.1 \%)\end{array}$ & $\begin{array}{l}95.4 \% \\
(90.4 \% \text { to } 97.9 \%)\end{array}$ & $\begin{array}{l}95.6 \% \\
\text { (89.6\% to } 98.3 \%\end{array}$ \\
\hline
\end{tabular}

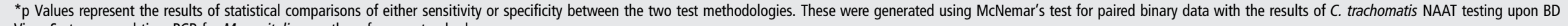
Viper System or real-time PCR for $M$. genitalium as the reference standards.

tUWCC were defined as positive if the patient's urine contained $>29$ White blood cell per $\mu \mathrm{L}$

¥GSUS testing containing $>5$ PMN per high power fields (HPFs) over 5 HPFs was examined.

FVU, first void urine; GSUS, Gram-stained urethral smear; NAAT, nucleic acid amplification testing; UWCC, urinary white cell counts.

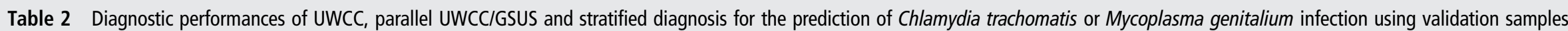
Diagnostic performance comparison of UWCC versus UWCC and GSUS performed in parallel using validation samples $(n=228)$

\begin{tabular}{|c|c|c|c|c|c|c|c|c|c|c|c|c|}
\hline & & UWCC* sensitivity & $\begin{array}{l}\text { Parallel } \\
\text { UWCC* and } \\
\text { GSUSt } \\
\text { sensitivity }\end{array}$ & $\begin{array}{l}p \\
\text { Value } \neq\end{array}$ & UWCC* specificity & $\begin{array}{l}\text { Parallel } \\
\text { UWCC* and GSUS } \\
\text { specificity }\end{array}$ & $\begin{array}{l}p \\
\text { Valueł }\end{array}$ & UWCC* & PPV§ & $\begin{array}{l}\text { Parallel UWCC } \\
\text { and GSUS } \\
\text { PPV§ }\end{array}$ & UWCC* NPVף & $\begin{array}{l}\text { Parallel UWCC and } \\
\text { GSUS NPVף }\end{array}$ \\
\hline C. trachomatis & & $\begin{array}{l}71.4 \% \\
\text { (42 to } 90.4 \text { ) }\end{array}$ & $\begin{array}{l}78.6 \% \\
\text { (48.8 to } 94.3)\end{array}$ & 0.5 & N/A & $\mathrm{N} / \mathrm{A}$ & & $\begin{array}{l}29.4 \% \\
\text { (15.7 to }\end{array}$ & 47.6) & $\begin{array}{l}26.8 \% \\
\text { (14.8 to } 43.2)\end{array}$ & $\begin{array}{l}97.9 \% \\
(94.4 \text { to } 99.3)\end{array}$ & $\begin{array}{l}98.3 \% \\
\text { (95 to } 99.5 \text { ) }\end{array}$ \\
\hline M. genitalium & & $\begin{array}{l}66.6 \% \\
\text { (35.4 to } 88.7 \text { ) }\end{array}$ & $\begin{array}{l}66.60 \% \\
\text { (35.4 to 88.7) }\end{array}$ & 0.25 & $N / A$ & $\mathrm{~N} / \mathrm{A}$ & & $\begin{array}{l}23.5 \% \\
(11.3 \text { to }\end{array}$ & 41.5) & $\begin{array}{l}19.5 \% \\
\text { (93 to } 35.3 \text { ) }\end{array}$ & $\begin{array}{l}97.9 \% \\
(94.4 \text { to } 99.3)\end{array}$ & $\begin{array}{l}97.9 \% \\
(94.3 \text { to } 99.3)\end{array}$ \\
\hline $\begin{array}{l}\text { C. trachomatis } \\
\text { or M. genitalium }\end{array}$ & & $\begin{array}{l}69.2 \% \\
(48.1 \text { to } 84.9)\end{array}$ & $\begin{array}{l}73 \% \\
\text { (51.9 to } 87.6)\end{array}$ & 0.031 & $\begin{array}{l}92 \% \\
(87.2 \text { to } 95.2)\end{array}$ & $\begin{array}{l}89.1 \% \\
\text { (83.7 to } 92.8)\end{array}$ & 0.03 & $\begin{array}{l}53 \% \\
(35.3 \text { to }\end{array}$ & 69.8) & $\begin{array}{l}46.3 \% \\
\text { (30.9 to } 60.3 \text { ) }\end{array}$ & $\begin{array}{l}95.8 \% \\
\text { (91.7 to } 98)\end{array}$ & $\begin{array}{l}96.2 \% \\
(92.1 \text { to } 98.3)\end{array}$ \\
\hline \multicolumn{13}{|c|}{ Diagnostic performance comparison of UWCC versus stratified diagnosis using validation samples of asymptomatic patients only $(n=176)$} \\
\hline & $\begin{array}{l}\text { UWCC* } \\
\text { sensitivity }\end{array}$ & $\begin{array}{l}\text { Stratified diagnosis** } \\
\text { sensitivity }\end{array}$ & $\begin{array}{l}p \\
\text { Value } \neq\end{array}$ & $\begin{array}{l}\text { UWCC* } \\
\text { specificity }\end{array}$ & $\begin{array}{l}\text { Stratified diagn } \\
\text { specificity }\end{array}$ & $\begin{array}{l}\mathrm{p} \\
\text { Valuef }\end{array}$ & \multicolumn{2}{|c|}{ UWCC* PPV§ } & \multicolumn{2}{|c|}{$\begin{array}{l}\text { Stratified diagnosis } \\
\text { PPV§ }\end{array}$} & UWCC* NPVף & $\begin{array}{l}\text { Stratified approach } \\
\text { NPVף }\end{array}$ \\
\hline C. trachomatis & $\begin{array}{l}100 \% \\
(40.3 \% \text { to } 100 \%)\end{array}$ & $\begin{array}{l}60 \% \\
(17 \% \text { to } 92.7 \%)\end{array}$ & 0.5 & N/A & N/A & & \multicolumn{2}{|c|}{$\begin{array}{l}19.2 \% \\
(7.3 \% \text { to } \\
39.9 \%)\end{array}$} & \multicolumn{2}{|c|}{$\begin{array}{l}30 \% \\
\text { (8\% to } 64.6 \%)\end{array}$} & $\begin{array}{l}100 \% \\
(96.8 \% \text { to } \\
100 \%)\end{array}$ & $\begin{array}{l}98.8 \% \\
(95.3 \% \text { to } 99.8 \%)\end{array}$ \\
\hline M. genitalium & $\begin{array}{l}50 \% \\
(17.4 \% \text { to } \\
82.6 \%)\end{array}$ & $\begin{array}{l}12.5 \% \\
(0.6 \% \text { to } 53.3 \%)\end{array}$ & 0.25 & N/A & N/A & & \multicolumn{2}{|c|}{$\begin{array}{l}15.4 \% \\
\text { (5\% to } 35.7 \%)\end{array}$} & \multicolumn{2}{|c|}{$\begin{array}{l}10 \% \\
\text { (0.5\% to } 45.9 \%)\end{array}$} & $\begin{array}{l}97.3 \% \\
(92.9 \% \text { to } \\
99.1 \%)\end{array}$ & $\begin{array}{l}95.8 \% \\
(91.1 \% \text { to } 98.1 \%)\end{array}$ \\
\hline $\begin{array}{l}\text { C. trachomatis } \\
\text { or } \\
\text { M. genitalium }\end{array}$ & $\begin{array}{c}71.4 \% \\
\text { (42\% to } 90.4 \%)\end{array}$ & $\begin{array}{l}28.6 \% \\
(9.6 \% \text { to } 58 \%)\end{array}$ & 0.031 & $\begin{array}{l}90.1 \% \\
(84.2 \% \text { to } 94 \%\end{array}$ & $\begin{array}{l}96.3 \% \\
(91.8 \% \text { to } 98.5 \%\end{array}$ & $<0.01$ & \multicolumn{2}{|c|}{$\begin{array}{l}38.5 \% \\
(20.9 \% \text { to } \\
59.3 \%)\end{array}$} & \multicolumn{2}{|c|}{$\begin{array}{l}40 \% \\
(13.7 \% \text { to } 72.6 \%)\end{array}$} & $\begin{array}{r}97.3 \% \\
(92.9 \% \text { to } \\
99.1 \%)\end{array}$ & $\begin{array}{l}93.8 \% \\
(88.9 \% \text { to } 96.9 \%)\end{array}$ \\
\hline
\end{tabular}

*UWCC were defined as positive if the patient's urine contained $>29$ White blood cell per $\mu \mathrm{L}$.

tGSUS testing containing $>5$ PMN per high power fields (HPFs) over 5 HPFs was examined.

¥p Values represent the results of statistical comparisons of either sensitivity or specificity between the two test methodologies. These were generated using McNemar's test for paired binary data with the results of $C$. trachomatis NAAT testing upon BD Viper System or real-time PCR for M. genitalium as the reference standards.

§Positive predictive value.

**Positive stratified diagnosis is defined as patients treated for urethritis due to suggestive clinical history.

GSUS, Gram-stained urethral smear; NAAT, nucleic acid amplification testing; UWCC, urinary white cell counts.

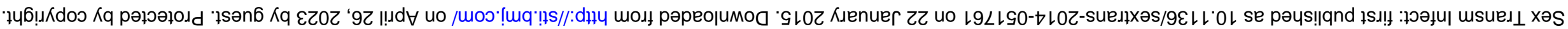


on an independent cohort of men, the majority of whom were asymptomatic, validated these findings albeit with a possible slight but expected reduction in specificity when UWCC were combined with GSUS. Our data suggest AUFC represents an improved PoC test for NGU when compared with microscopy for predicting urethritis caused by C. trachomatis or M. genitalium. However, first-line treatments for the two pathogens are different. In the absence of pathogen-specific PoC tests, positive AUFC might best be used as per NGU management guidelines or as prescreening for using pathogen-specific PoC tests when the latter become available.

Associations between PMN leucocyte counts present within FVU sediment and urethral exudate specimens were first observed by Bowie. ${ }^{2}$ More recently, microscopic enumeration of antibody-stained white cells within FVU s was used to study the association between leucocyte counts and urethral pathogens, ${ }^{16}$ a technique unsuitable for high throughput use. GSUS has therefore remained predominantly in use for diagnosing urethritis on account of its technical simplicity.

Compared with GSUS, AUFC is simple to perform, rapid (within a few minutes), offers increased throughput and obviates the need for invasive urethral swabbing. These features will improve patient acceptability and potentially allow for triaging patients into those with and without urethritis on entering the clinic. Incorporation of further improvements in portability of flow cytometric devices ${ }^{17}$ may allow for use in outreach settings, enabling many more patients to be screened rapidly for urethritis without the need to attend tertiary healthcare for diagnosis.

Preliminary experiments carried out alongside this study (data not shown) suggest AUFC is capable of detecting inflammation caused by gonococcal infection. A potential pitfall of replacing GSUS with AUFC is the loss of PoC diagnosis of $N$. gonorrhoeae infection. Observation of intracellular Gram-negative diplococci upon GSUS possesses sensitivities and specificities approaching $100 \%$ for the diagnosis of gonorrhoea. ${ }^{18}$ Our results suggest continuing to deploy GSUS in symptomatic patients alongside UWCC testing for all patients would retain PoC N. gonorrhoeae detection while maximising the sensitivity of screening for C. trachomatis and M. genitalium. Future application of AUFC in parallel with accurate PoC NAAT testing for gonorrhoea ${ }^{19}$ should overcome the requirement to retain GSUS.

The sensitivity of GSUS in predicting chlamydial infection in our study was $93.7 \%$ in comparison with $23-63 \%$ in previous studies using NAATs, a difference possibly attributable to increased sensitivity of the C. trachomatis test platform we used $\left(B D\right.$ Viper NAAT) ${ }^{20}$ when compared with these other studies. ${ }^{721}$ Our study was not powered to demonstrate a difference in sensitivity between GSUS and AUFC, although we believe the benefits in specificity and the non-invasive nature of AUFC represent real clinical advantages. The specificity of AUFC was likely compromised because we evaluated the accuracy of predicting C. trachomatis or M. genitalium infections, together which usually account for half of NGU causes. All study samples were screened for Trichomonas vaginalis but a very low prevalence was observed (data not shown), precluding its inclusion in this study. Wider population-based studies characterised for larger sets of known ${ }^{22}$ and candidate ${ }^{23}$ causes of NGU may allow further assessment of AUFC test performance.

Asymptomatic patients did not form part of training set samples and therefore the identified FVU-UWCC threshold may not be optimal for identification of urethral infection in these patients. Inclusion of asymptomatic patients within training samples would have required them to receive unnecessary and potentially uncomfortable GSUS testing, which is not recommended by current guidelines. In this study we applied Youden's index of J, a methodology that applies equal weighting to both sensitivity and specificity when determining the threshold of diagnostic test positivity. In future, separately developed thresholds for asymptomatic patients may be necessary for maximum test performance, with potentially greater weight given to specificity to prevent inappropriate overtreatment of patients.

GSUS and AUFC results did not demonstrate absolute congruence. Four M. genitalium-infected patients and three C. trachomatis-infected patients were positive by GSUS but demonstrated $<29$ UWCC $/ \mu \mathrm{L}$ by AUFC. Bacterial loads for both organisms in these patients were significantly lower than the remaining infected patients, suggesting AUFC may lack sensitivity for predicting infections with a low bacterial burden. Five patients infected with $M$. genitalium and two with C. trachomatis were positive using AUFC but negative by GSUS, perhaps attributable to technical and observer variations in GSUS. ${ }^{5}$ These patients did not demonstrate reduced bacterial loads. Within validation samples, 13 M. genitalium-positive patients or C. trachomatis-positive patients did not undergo microscopy as they were asymptomatic and not required to do so. ${ }^{12}$ Three of these patients were asymptomatic contacts of CT and of these two were UWCC positive.

Associations between bacterial load and UWCC gave insight into pathogenesis and potential interactions with other infections. First, we demonstrated C. trachomatis-infected patients possessed significantly higher UWCC when compared with M. genitalium-positive patients. In order to further investigate this finding, we assessed the relationship between UWCC and pathogen load. Bacterial load range of M. genitalium was comparable with other studies ${ }^{24} 25$ and there was no difference in pathogen loads between M. genitalium and C. trachomatis, although this analysis was a secondary outcome of the study and may not have been sufficiently powered to demonstrate this. However, UWCC were higher in C. trachomatis infection compared with M. genitalium, suggesting different interactions or effects of inflammation on bacterial replication in the male genital tract between the two organisms. ${ }^{26}{ }^{27}$ Second, C. trachomatis bacterial loads have been shown to be present at 100 -fold greater concentrations than M. genitalium on vaginal swabs, and higher in vaginal swabs compared with male FVU ${ }^{28} 29$ samples. Our findings of similar loads of C. trachomatis and M. genitalium within male FVU samples perhaps suggest an altered pathogenesis between male and female infections. Finally, the observation of a strong proportionate relationship between bacterial burden and inflammatory response observed in this study for M. genitalium supports recent observations that levels of genital HIV secretion are increased when M. genitalium burden is high. ${ }^{30}$

\section{Key messages}

Automated flow cytometric analysis of first void urine specimens for the presence of elevated urine white cell counts (UWCCS) is a practical method for screening patients for the detection of urethral infection.

- This technique is non-invasive, user-independent, rapid and has enhanced diagnostic specificity when compared with gram-stained urethral smear.

- Application of this test may allow for and improve the diagnosis of urethritis in patients who do not report symptoms.

- UWCC are related to pathogen load and may be useful in field and community studies of patients with STIs. 
In conclusion, in the absence of PoC tests capable of detecting common causes of NGU, and decreased use of GSUS, implementation of automated UWCC may be an attractive, accurate, PoC screening test for urethritis and urethral infection in symptomatic and asymptomatic men, enabling immediate syndromic management for a greater number of patients infected with either C. trachomatis or M. genitalium.

\section{Handling editor Jackie A Cassell}

Acknowledgements The authors would like to thank the departments of medical microbiology and genitourinary medicine at St Georges NHS Trust for their assistance in conducting this study. They acknowledge Bio-Rad for provision of ddPCR.

Contributors MJP conceived and designed the study, collected and processed the samples, analysed the data and drafted and revised the manuscript. AVN collected data, analysed the data and contributed to the manuscript. SP aided in the implementation of the study and the collection of samples and clinical data. KL oversaw the molecular techniques, analysis of the generated data and contributed to the manuscript. MA contributed to the sample processing, molecular techniques and data analysis. AJC guided the study design, supported the statistical analysis and drafted and revised the manuscript. PDB critically appraised the research and revised the manuscript. PH participated in the design of the study and critical appraisal of the manuscript. STS conceived and designed the study, analysed the data and revised the manuscript.

Funding Funded under the UKCRC Translational Infection Research (TIR) Initiative supported by the Medical Research Council (Grant Number G0901608) with contributions to the Grant from the Biotechnology and Biological Sciences Research Council, the National Institute for Health Research on behalf of the Department of Health, the Chief Scientist Office of the Scottish Government Health Directorates and the Wellcome Trust.

\section{Competing interests None.}

Ethics approval Wandsworth Research Ethics Committee, London.

Provenance and peer review Not commissioned; externally peer reviewed.

Open Access This is an Open Access article distributed in accordance with the terms of the Creative Commons Attribution (CC BY 4.0) license, which permits others to distribute, remix, adapt and build upon this work, for commercial use, provided the original work is properly cited. See: http://creativecommons.org/ licenses/by/4.0/

\section{REFERENCES}

1 Martin DH. Urethritis in males. In: Holmes KK, Sparling PF, Stamm WE, et al, eds. Sexually Transmitted Diseases. 4th edn. New York: McGraw-Hill, 2008:1107-27.

2 Bowie WR. Comparison of Gram stain and first-voided urine sediment in the diagnosis of urethritis. Sex Transm Dis 1978:5:39-42.

3 Swartz SL, Kraus SJ, Herrmann KL, et al. Diagnosis and etiology of nongonococcal urethritis. J Infect Dis 1978;138:445-54.

4 Apoola A, Herrero-Diaz M, FitzHugh E, et al. A randomised controlled trial to assess pain with urethral swabs. Sex Transm Infect 2011;87:110-13.

5 Smith R, Copas AJ, Prince M, et al. Poor sensitivity and consistency of microscopy in the diagnosis of low grade non-gonococcal urethritis. Sex Transm Infect 2003;79:487-90.

6 Willcox JR, Adler MW, Belsey EM. Observer variation in the interpretation of Gram-stained urethral smears: implications for the diagnosis of non-specific urethritis. Br J Vener Dis 1981;57:134-36.

7 Haddow LJ, Bunn A, Copas AJ, et al. Polymorph count for predicting non-gonococcal urethral infection: a model using Chlamydia trachomatis diagnosed by ligase chain reaction. Sex Transm Infect 2004;80:198-200.

8 Broeren MA, Bahceci S, Vader HL, et al. Screening for urinary tract infection with the Sysmex UF-1000i urine flow cytometer. J Clin Microbiol 2011;49:1025-29.
9 Jolkkonen S, Paattiniemi EL, Karpanoja P, et al. Screening of urine samples by flow cytometry reduces the need for culture. J Clin Microbiol 2010;48:3117-21.

10 Pieretti B, Brunati P, Pini B, et al. Diagnosis of bacteriuria and leukocyturia by automated flow cytometry compared with urine culture. J Clin Microbiol 2010;48:3990-6.

11 Pond MJ, Nori AV, Witney AA, et al. High prevalence of antibiotic-resistant Mycoplasma genitalium in nongonococcal urethritis: the need for routine testing and the inadequacy of current treatment options. Clin Infect Dis 2014;58:631-7.

12 British Association for Sexual Health and HIV. Sexually Transmitted Infections: UK national screening and testing guidelines. 31-8-2006. 1-8-2006.

13 Naccarato WF, Treuting JJ, Cannon DC. Gravimetric determination of urine volumes. Am J Med Technol 1981;47:111-12.

14 Schaeffer A, Henrich B. Rapid detection of Chlamydia trachomatis and typing of the Lymphogranuloma venereum associated L-Serovars by TaqMan PCR. BMC Infect Dis 2008;8:56.

15 Jensen JS, Bjornelius E, Dohn B, et al. Use of TaqMan 5' nuclease real-time PCR for quantitative detection of Mycoplasma genitalium DNA in males with and without urethritis who were attendees at a sexually transmitted disease clinic. J Clin Microbiol 2004;42:683-92.

16 Wiggins RC, Holmes $\mathrm{CH}$, Andersson $\mathrm{M}$, et al. Quantifying leukocytes in first catch urine provides new insights into our understanding of symptomatic and asymptomatic urethritis. Int J STD AIDS 2006;17:289-95.

17 Moon S, Gurkan UA, Blander J, et al. Enumeration of CD4+ T-cells using a portable microchip count platform in Tanzanian HIV-infected patients. PloS One 2011;6:e21409.

18 Taylor SN, DiCarlo RP, Martin DH. Comparison of methylene blue/gentian violet stain to Gram's stain for the rapid diagnosis of gonococcal urethritis in men. Sex Transm Dis 2011;38:995-96.

19 Gaydos CA, Van Der PB, Jett-Goheen M, et al. Performance of the Cepheid CT/NG Xpert rapid PCR test for detection of Chlamydia trachomatis and Neisseria gonorrhoeae. J Clin Microbiol 2013;51:1666-72.

20 Taylor SN, Van Der PB, Lillis R, et al. Clinical evaluation of the BD ProbeTec Chlamydia trachomatis Qx amplified DNA assay on the BD Viper system with XTR technology. Sex Transm Dis 2011;38:603-9.

21 Orellana MA, Gomez-Lus ML, Lora D. Sensitivity of Gram stain in the diagnosis of urethritis in men. Sex Transm Infect 2012;88:284-87.

22 Bradshaw CS, Tabrizi SN, Read TR, et al. Etiologies of nongonococcal urethritis: bacteria, viruses, and the association with orogenital exposure. J Infect Dis 2006;193:336-45.

23 Manhart LE, Khosropour CM, Liu C, et al. Bacterial vaginosis-associated bacteria in men: association of Leptotrichia/Sneathia spp. with nongonococcal urethritis. Sex Transm Dis 2013:40:944-9.

24 Dupin N, Bijaoui G, Schwarzinger M, et al. Detection and quantification of Mycoplasma genitalium in male patients with urethritis. Clin Infect Dis 2003;37:602-5.

25 Muller EE, Venter JM, Magooa MP, et al. Development of a rotor-gene real-time PCR assay for the detection and quantification of Mycoplasma genitalium. J Microbiol Methods 2012;88:311-15.

26 Falk L, Fredlund $H$, Jensen JS. Symptomatic urethritis is more prevalent in men infected with Mycoplasma genitalium than with Chlamydia trachomatis. Sex Transm Infect 2004;80:289-93.

27 Leung A, Eastick K, Haddon LE, et al. Mycoplasma genitalium is associated with symptomatic urethritis. Int J STD AIDS 2006;17:285-88.

28 Jalal $\mathrm{H}$, Verlander NQ, Kumar N, et al. Genital chlamydial infection: association between clinical features, organism genotype and load. J Med Microbiol 2011;60:881-88

29 Michel CE, Sonnex C, Carne CA, et al. Chlamydia trachomatis load at matched anatomic sites: implications for screening strategies. J Clin Microbiol 2007:45:1395-02.

30 Manhart LE, Mostad SB, Baeten JM, et al. High Mycoplasma genitalium organism burden is associated with shedding of HIV-1 DNA from the cervix. J Infect Dis 2008; 197:733-36. 